\title{
Detection and Characterization of the Cyanobacteria and Cyanophages of Barnegat Bay, New Jersey
}

\author{
Roksana M. Rahman', Alexandra Greco ${ }^{1}$, Alisha Nanda ${ }^{1}$, Christian Rios-Ruiz ${ }^{1}$, Yan Wang1, \\ Paul Yoon', Dena J. Restaino², John J. Gaynor ${ }^{3}$, Paul A. X. Bologna ${ }^{3}$, Tinchun Chu ${ }^{1 *}$ (1) \\ ${ }^{1}$ Department of Biological Sciences, Seton Hall University, NJ, USA \\ ${ }^{2}$ Department of Biology and Chemistry, County College of Morris, Randolph, NJ, USA \\ ${ }^{3}$ Department of Biology, Montclair State University, NJ, USA \\ Email: *Tin-Chun.Chu@shu.edu
}

How to cite this paper: Rahman, R.M., Greco, A., Nanda, A., Rios-Ruiz, C., Wang, Y., Yoon, P., Restaino, D.J., Gaynor, J.J., Bologna, P.A.X. and Chu, T.C. (2019) Detection and Characterization of the Cyanobacteria and Cyanophages of Barnegat Bay, New Jersey. Journal of Environmental Protection, 10, 1472-1483.

https://doi.org/10.4236/jep.2019.1011087

Received: September 16, 2019

Accepted: September 23, 2019

Published: November 6, 2019

Copyright $\odot 2019$ by author(s) and Scientific Research Publishing Inc. This work is licensed under the Creative Commons Attribution-NonCommercial International License (CC BY-NC 4.0). http://creativecommons.org/licenses/by-nc/4.0/ (c) (i) (8) Open Access

\begin{abstract}
Cyanobacterial harmful algal blooms (CHAB), caused by eutrophication, are known to threaten both wildlife and human health. Due to urbanization and land use changes, an increase of CHAB's at a more frequent rate within Barnegat Bay has been observed. In order to detect possible $\mathrm{CHAB}$ causing cyanobacteria, water samples were collected from 12 different locations within Barnegat Bay. Each sample was filtered through a 30- and 0.4- $\mu \mathrm{m}$ polycarbonate filter sequentially. Flow cytometry was carried out for the filtrate collected between $0.4-$ and $30-\mu \mathrm{m}$. Chelex DNA extraction, polymerase chain reaction (PCR), and gel electrophoresis were then performed for all sites using four primer sets (27F/785R, PSF/UR, CYA359F/CYA781R and MSF/MSR) designed to detect cyanobacteria. Flow cytometric results indicated the water samples contained a wide range of cyanobacteria, including M. aeruginosa, Cylindrospermum spp., Anabaena spp., and Synechococcus sp. IU 625 ranges from 3.16 to $8.17 \times 10^{7}$ cells. $\mathrm{L}^{-1}$. PCR-based assays suggest that general cyanobacteria as well as phytospecific species were present for all sites, but no toxin-producing Microcystis aeruginosa was detected. Plaque assays demonstrated the presence of cyanophages for $S$. IU 625, Anabaena spp., and $M$. aeruginosa at all sites, up to $10^{5} \mathrm{PFU} \cdot \mathrm{ml}^{-1}$.
\end{abstract}

\section{Keywords}

Cyanobacterial Harmful Algal Blooms, Eutrophication, Flow Cytometry, Polymerase Chain Reaction, Plaque Assay 


\section{Introduction}

Cyanobacterial harmful algal blooms (CHABs) have a negative effect on bodies of water globally. CHABs are produced by an overgrowth of cyanobacteria which can create hypoxic conditions and release toxins that can severely harm both wildlife and humans [1] [2]. Side effects of these toxins include respiratory issues, digestive tract issues, memory loss, seizures, skin irritation, and lesions [1]-[9]. CHABs can even be harmful enough to kill birds, fish, and humans [3]. The main cause of CHABs is eutrophication, where excess nutrients enter a body of water and result in uncontrolled growth of cyanobacteria; in particular, a surplus of phosphorous or nitrogen, which are normally the limiting factors of growth for photosynthetic organisms, is linked to human activity [10]. Anthropogenic modifications, such as domestic water use, agricultural, recreational, and industrial activity, construction, and sewage effluent all contribute to cultural eutrophication [10] [11]. Phosphorous levels have increased 8-fold in comparison to pre-industrial and pre-agricultural levels and nitrogen levels have increased at an even faster rate [10]. Cyanobacterial blooms have increasingly been of interest because their negative effects are costly. For example, from 1987 to 1992 the USA lost $\$ 49$ million in economic benefits due to CHABs [3].

According to the National Oceanic and Atmospheric Administration's National Estuarine Eutrophication Assessment model, Barnegat Bay has high levels of eutrophication which has only worsened over time. Eutrophication and CHABs in Barnegat Bay have caused the loss of aquatic vegetation, changes in benthic communities, as well as damage to shellfish [11]. The rise in population and urbanization within the Barnegat Bay watershed, coupled with minimal freshwater input and low flushing, only further exacerbates eutrophication. This potential threat to the delicate ecological balance of this important estuary and the potential harm to humans makes studying Barnegat Bay and CHABs essential.

Flow cytometry has become a rapid and efficient way to determine the microbial community in environmental samples. Flow cytometry analyzes cells in a single stream-one cell at a time-using lasers to determine the optical characteristics of cells. Flow cytometry is able to determine cell count, cell size, granularity, as well as other physiological characteristics. Cyanobacteria can be readily characterized using flow cytometry methods as they already contain fluorescent proteins called phycobiliproteins [12] [13] [14]. The pigments phycoerythrin, a red pigment, and allophycocyanin, a light blue pigment, are easily detected in flow cytometry allowing for an even more rapid detection of cyanobacteria than other bacteria not containing these proteins [15] [16] [17]. This allows for the rapid determination of different cell types against a known standard [13]. Polymerase Chain Reaction (PCR) is a widely used molecular tool to detect the presence of the microorganisms [18] [19]. It can also be utilized as a supplement to flow cytometry to validate and verify the specific cyanobacterial presence in the water [13]. 
A natural system that may aid in controlling the growth of CHABs is the presence of cyanophages. Cyanophages are bacteriophages that have the ability to infect and lyse cyanobacteria [20]. Cyanophages alter populations of cyanobacteria and can play a role in community composition, depending on the cyanophage types present. Given their ability to affect community structure, cyanophages have a critical role in reducing the frequency and strength of CHABs [20] [21]. The aim of this study is to rapidly detect and characterize the cyanobacteria and their phages of Barnegat Bay. The findings will help monitor the potential CHABs.

\section{Materials and Methods}

\subsection{Environmental Sample Collection}

Surface water samples were collected in August 2018 from 12 sites within Barnegat Bay. Upon collection, GPS coordinates and water quality parameters including dissolved oxygen $(\mathrm{mg} / \mathrm{L})$, dissolved oxygen percentage, salinity, and temperature were recorded. Samples were collected from the following sites: Bayshore Lagoon (BSL), Double Creek East (DCE), Double Creek West (DCW), Forked River East (FRE), Forked River Lagoon (FRL), Forked River West (FRW), Forked River Route 9 (FR9), Oyster Creek Mouth (OCM), Oyster Creek Outlet (OCO), Sunrise Beach Lagoon (SBL), Sunrise Beach Open Water (SBOW), and Toms River West (TRW) (Figure 1).

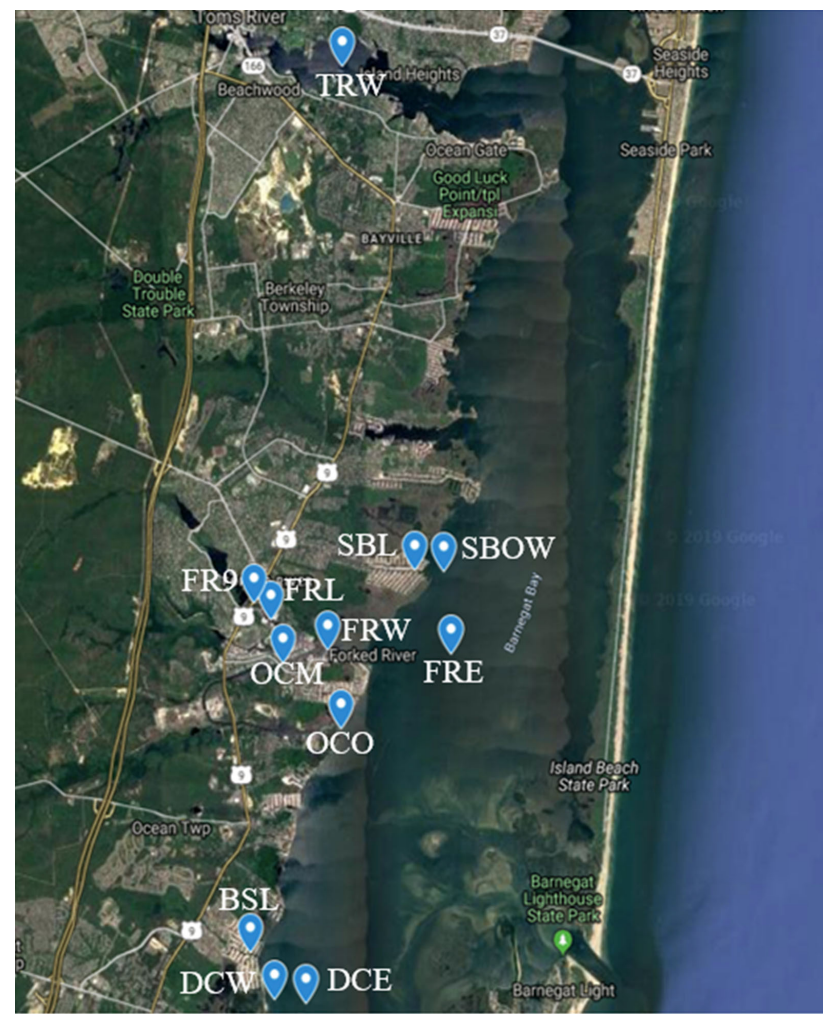

Figure 1. Map of New Jersey Barnegat bay collection sites (Google Maps, 2019). 


\subsection{Sample Processing}

Using a polycarbonate $30 \mu \mathrm{m}$ filter (Sterlitech, Kent, WA, USA), $500 \mathrm{ml}$ of each sample was filtered and $100 \mathrm{ml}$ of this filtrate was reserved for flow cytometry. The remaining $400 \mathrm{ml}$ filtrate was then filtered through a polycarbonate $0.4 \mu \mathrm{m}$ filter (Sterlitech, Kent, WA, USA). This process was repeated for all 12 collection sites. Additionally, the filters used for each sample were set aside to dry for further analysis.

\subsection{Flow Cytometry}

Flow cytometry was used to compare the community of cyanobacteria present within the 12 sites collected at Barnegat Bay to a set of preset standards using a MACSQuant Analyzer (Miltenyi Biotec, Inc., San Diego, CA, USA). The $100 \mu \mathrm{l}$ of filtrate less than 30 microns was used for flow cytometry analysis of the Barnegat Bay samples [22]. The samples were overlaid on top of the standards in order to determine the community composition using FlowJo 10.5.2 (Tree Star Inc., Ashland, OR, USA).

\subsection{Molecular Analysis of Water Samples}

DNA was extracted from the $0.4 \mu \mathrm{m}$ filters using Chelex ${ }^{\circledR}[6]$. This process was repeated twice for each collection site. To assess the presence of various prokaryotes in samples, four sets of molecular primers were selected to determine bacteria, photosynthetic bacteria, cyanobacteria, and toxin producing Microcystis aeruginosa [23] [24] [25] [26] (Table 1). Using each primer set, a PCR was performed on the DNA extracted from the 12 Barnegat Bay sites using GoTaq Hot Start Green Master mix (Promega, Madison, WI, USA) and amplified in a Veriti 96 Well Thermocycler (Applied Biosystems, Carlsbad, CA, USA). Amplicons were assessed on a $1 \%(\mathrm{w} / \mathrm{v})$ agarose gel (113 V for 45 minutes) using a GeneRuler $1 \mathrm{~Kb}$ Plus DNA Ladder (Thermo Scientific, CA, USA).

Table 1. DNA primers used to assess prokaryote presence in samples.

\begin{tabular}{|c|c|c|c|c|c|}
\hline $\begin{array}{l}\text { Primer } \\
\text { Name }\end{array}$ & Primer Sequence & $\begin{array}{l}\mathrm{Tm} \\
\left({ }^{\circ} \mathrm{C}\right)\end{array}$ & $\begin{array}{l}\text { Amplicon } \\
\text { Size (nt) }\end{array}$ & Gene & Source \\
\hline $\begin{array}{l}27 \mathrm{~F} \\
785 \mathrm{R}\end{array}$ & $\begin{array}{l}\text { AGAGTTTGATCCTGGCTCAG } \\
\text { ACTACCRGGGTATCTAATCC }\end{array}$ & 50 & 740 & $\begin{array}{l}\text { Bacterial } \\
16 \mathrm{~S} \text { rRNA }\end{array}$ & {$[23]$} \\
\hline PSF & $\begin{array}{l}\text { GGGATTAGATACCCCWGTAGTCCT } \\
\text { ACGGYTACCTTGTTACGACTT }\end{array}$ & 53 & 735 & $\begin{array}{l}\text { Phytospecific } \\
\text { 16S rRNA }\end{array}$ & [25] \\
\hline $\begin{array}{l}\text { CYA359F } \\
\text { CYA781R }\end{array}$ & $\begin{array}{l}\text { GGGGAATYTTCCGCAATGGG } \\
\text { GACTACWGGGGTATCTAATCCCWTT }\end{array}$ & 50 & 426 & $\begin{array}{l}\text { Cyanobacterial } \\
16 \mathrm{~S} \text { rRNA }\end{array}$ & {$[24]$} \\
\hline $\begin{array}{l}\text { MSF } \\
\text { MSR }\end{array}$ & $\begin{array}{l}\text { ATCCAGCAGTTGAGCAAGC } \\
\text { TGCAGAAAACTCCGCAGTTG }\end{array}$ & 58 & 1369 & mcyA & {$[26]$} \\
\hline
\end{tabular}




\subsection{Plaque Assay}

To determine the presence of cyanophages the $0.4 \mu \mathrm{m}$ filter filtrate was ultracentrifuged for 2 hours at 17,500 rpm to concentrate the sample. Plaque assays containing a mix of several cyanobacterial strains Anabaena spp., Synechococcus sp. IU 625, Microcystis aeruginosa sp. UTEX 2386, Microcystis aeruginosa sp. UTEX 2385 and Cylindrospermum spp. were used in order to determine the presence of cyanophages. Individual cyanobacteria strains were also used in order to determine whether cyanophages targeted a particular cyanobacterium. Individual strains used were Synechococcus sp. IU 625, Anabaena spp., Microcystis aeruginosa sp. UTEX 2385, and Oscillatoria spp. The cyanobacterial mix or individual cyanobacterial strains were concentrated and $200 \mu \mathrm{l}$ of concentrated filtrate from one site within Barnegat Bay was added, and then incubated for 1 hour. Next, $1 \mathrm{ml}$ of a $1 \%(\mathrm{w} / \mathrm{v})$ agar mixture was added to the sample and vortexed. Each mixture was poured onto a BG-11 agar plate and then tilted to ensure it was evenly spread. Photos of the plaque assay plates were then taken daily for 16 days, in which 4 time points were chosen to display the formation of plaques over time.

\section{Results}

\subsection{Water Quality}

For water chemistry of the 12 sites, the dissolved oxygen ranged from $5.60 \mathrm{mg} / \mathrm{l}$ to $7.08 \mathrm{mg} / \mathrm{l}$, the dissolved oxygen percentage ranged from $77.0 \%$ to $98.3 \%$, the salinity ranged from 13.2 parts per thousand (ppt) to $26.8 \mathrm{ppt}$, and the temperature ranged from $24.3^{\circ} \mathrm{C}$ to $28.3^{\circ} \mathrm{C}$. The highest temperatures recorded are for the Oyster Creek Mouth and Outlet $\left(28.2^{\circ} \mathrm{C}\right.$ and $\left.28.3^{\circ} \mathrm{C}\right)$, which represents the effluent for the heat exchangers from the Oyster Creek Nuclear Generating Station. The inlet side is the Forked River, which had temperatures of $24.6^{\circ} \mathrm{C}$ (FR9) and $24.9^{\circ} \mathrm{C}(\mathrm{FRW})$. The temperature differential on this day averaged $3.5^{\circ} \mathrm{C}$ warmer on the Oyster Creek than other sites sampled (Table 2).

Table 2. Water chemistry of 12 collection sites within Barnegat Bay.

\begin{tabular}{|c|c|c|c|c|}
\hline Collection Site & Dissolved Oxygen $(\mathrm{mg} / \mathrm{l})$ & Dissolved Oxygen (\%) & Salinity (ppt) & Temperature $\left({ }^{\circ} \mathrm{C}\right)$ \\
\hline Bayshore Lagoon (BSL) & 6.33 & 89.1 & 23.2 & 26.8 \\
\hline Double Creek East (DCE) & 6.82 & 95.3 & 26.7 & 25.5 \\
\hline Double Creek West (DCW) & 7.01 & 98.3 & 26.8 & 25.5 \\
\hline Forked River East (FRE) & 6.04 & 82.1 & 26.2 & 24.4 \\
\hline Forked River Lagoon (FRL) & 5.45 & 78.8 & 25.8 & 26.5 \\
\hline Forked River West (FRW) & 6.02 & 82.7 & 26.1 & 24.9 \\
\hline Forked River Route 9 (FR9) & 5.65 & 77.0 & 25.3 & 24.6 \\
\hline Oyster Creek Mouth (OCM) & 5.67 & 83.1 & 24.9 & 28.2 \\
\hline Oyster Creek Outlet (OCO) & 5.6 & 81.2 & 24.8 & 28.3 \\
\hline Sunrise Beach Lagoon (SBL) & 6.18 & 87.1 & 24.6 & 26.0 \\
\hline Sunrise Beach Open Water (SBOW) & 7.08 & 97.2 & 24.0 & 25.2 \\
\hline Toms River West (TRW) & 6.61 & 84.0 & 13.2 & 24.3 \\
\hline
\end{tabular}




\subsection{Flow Cytometry}

In analyzing the samples using phycoerythrin (PE) and allophycocyanin (APC), all 12 sites were found to have the presence of cells similar to Synechococcus sp. IU 625, Cylindrospermum spp. and Anabaena spp. All samples, with the exception of Bayshore Lagoon, also had Microcystis aeruginosa like cells present within the sample (Figure 2). However, none of the samples had cells similar to Oscillatoria spp.
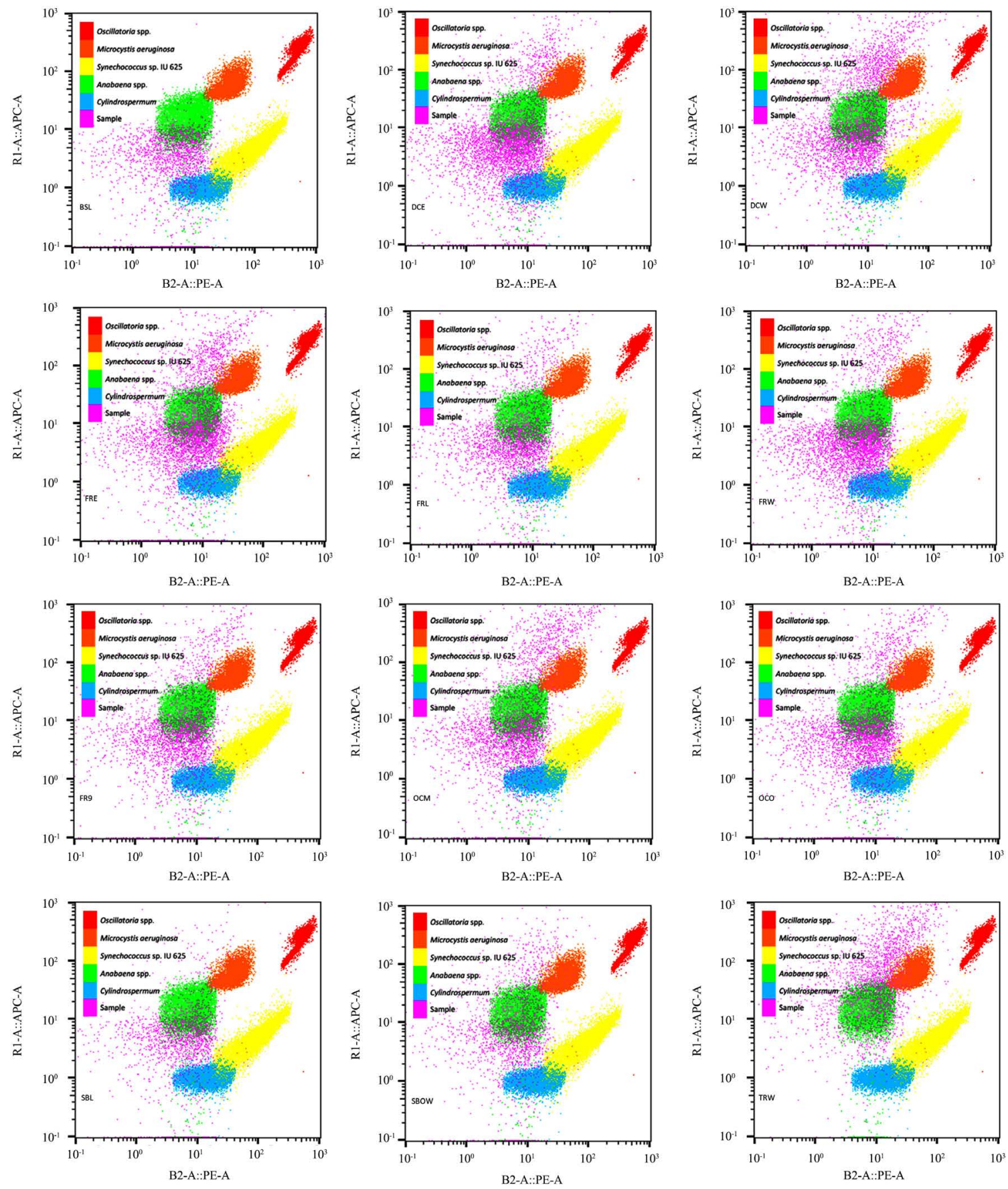

Figure 2. Phycoerythrin (PE)-allophycocyanin (APC) gated profile for all 12 collection sites. 


\subsection{PCR and Gel Electrophoresis}

Molecular analyses using the four primer sets indicate the presence of bacteria, photospecific bacteria, and cyanobacteria (Figures 3(a)-(c)) at all 12 sampling sites. In all reactions, no template controls (NC) were negative as expected. In addition, no amplicons (1369 bp) were observed for Microcystis aeruginosa (data not shown), suggesting that there were no toxin producing cells present at these 12 sites.

\subsection{Plaque Assay}

A mixed culture of Anabaena, Microcystis aeruginosa UTEX 2385, Microcystis aeruginosa UTEX 2386, Synechococcus sp. IU 625, and Cylindrospermum were used to detect the presence of cyanophages. Using this mixed culture, cyanophages were detected up to $10^{5} \mathrm{PFU} \cdot \mathrm{ml}^{-1}$ by plaque formation on plates from all 12 sites. After detecting viral plaques for the mixed cyanobacterial culture (Figure 4), individual strains of Anabaena spp., Microcystis aeruginosa UTEX 2386, Synechococcus sp. IU 625, Cylindrospermum spp., and Oscillatoria spp. were plated to evaluate taxa-specific cyanophages. Results from these individual plaque assays indicated cyanophages were present for all 12 sites for Anabaena spp., Microcystis aeruginosa UTEX 2386, and Synechococcus sp. IU 625. However, no evidence of cyanophage plaques relating to Cylindrospermum spp. and Oscillatoria spp. were identified.

\section{Discussion}

Three methodologies were incorporated in this study: flow cytometry, PCR based assays, and plaque assays. This finding is encouraging considering the wide range of negative side effects $M$. aeruginosa toxins can have on wildlife and humans. Flow cytometry use is on the rise when it comes to determining the presence of cyanobacteria within water samples due to its ability to rapidly detect a wide range of different types of cells [27]. Flow cytometry is a useful method is determining the composition of water samples because it is fairly quick once standards are established [13]. This can give a general idea as to whether water samples potentially have cyanobacterial strains that are concerning to public health in a short time frame. This is important when time and resources are limited because flow cytometry can help to determine what water samples need to be focused on for further testing. In analyzing the relationship between water quality and flow cytometry, it was determined that salinity may have affected the populations within the collection sites. Higher salinity seemed to correlate with two densely clustered populations within a collection site as seen in Double Creek East, Double Creek West, and Forked River East. Lower salinity was associated with a different single cluster population as seen in Bayshore Lagoon and Toms River West. In looking at PE by APC, similarities are seen if they are examined by geographical location, sites near each other have similar cluster patterns which are expected. Double Creek East and Double Creek 

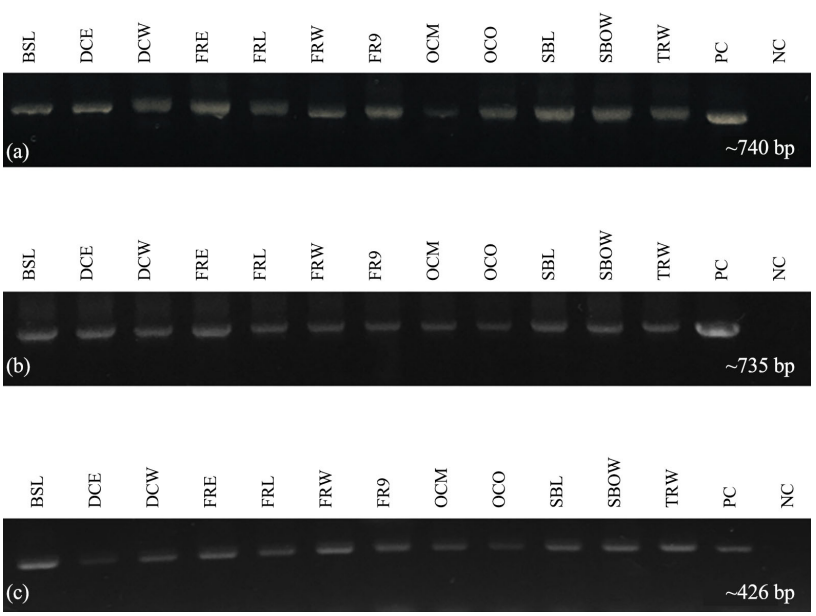

Figure 3. Gel images of (a) PCR products using the primer set $27 \mathrm{~F} / 785 \mathrm{R}$ (740 bp) for all 12 sites. Universal bacteria were detected for all sites; (b) PCR products using the primer set PSF/UR (735 bp) for all 12 sites. Phytospecific bacteria were detected for all sites; (c) PCR products using the primer set CYA359F/CYA781R (426 bp) for all 12 sites. cyanobacteria were detected for all sites.

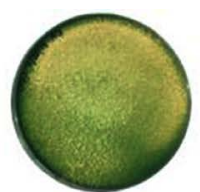

Day 4

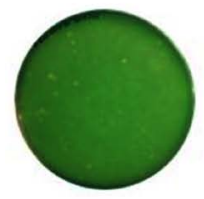

Day 4

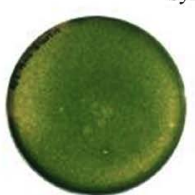

Day 5

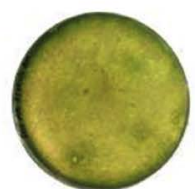

Day 11

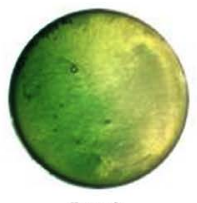

Day 2

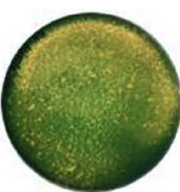

Day 5 Mixed Cyanobacteria Plaque Assay - Double Creek East

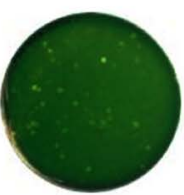

Day 5

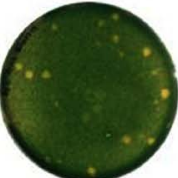

Day 6

Anabaena spp. Plaque Assa

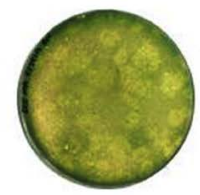

Day 12

Microcystis aeruginosa Plaque Assay - Double Creek East

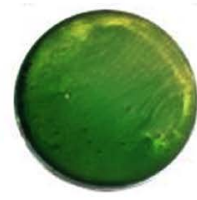

Day 3

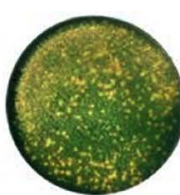

Day 6

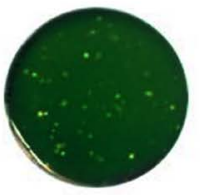

Day 9

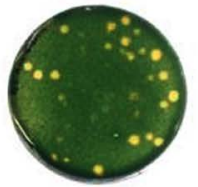

Day 7

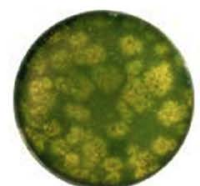

Day 13

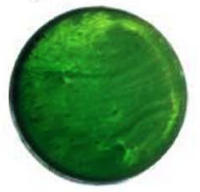

Day 4

Oscillatoria spp. Plaque Assay - Sunrise Beach Lagoon

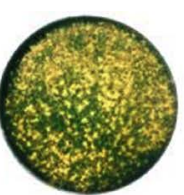

Day 7

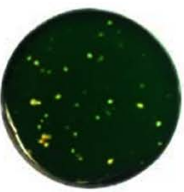

Day 11

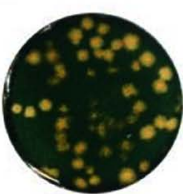

Day 9

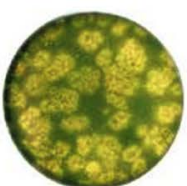

Day 14

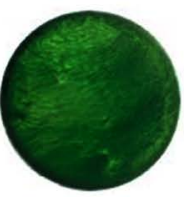

Day 5

Figure 4. Representative plaque assay plate images of mixed and individual cyanobacterial strains. 
West had similar cluster patterns, however Bayshore Lagoon varied from these two sites even though it is geographically close. Bayshore Lagoon is a manmade lagoon which may explain as to why is it different than Double Creek East and Double Creek West. Forked River Lagoon, Forked River West, and Forked River Route 9 had similar cluster patterns and are geographically close to one another. Oyster Creek Mouth, Oyster Creek Outlet, and Forked River East had similar cluster patterns and are geographically close to one another. Sunrise Beach Lagoon and Sunrise Beach Open Water had similar cluster patterns and are geographically close to one another. Lastly, Toms River West is geographically isolated from the other collection sites and has a unique cluster pattern. These results were not surprising since different geographical locations are expected to vary slightly in cluster patterns. Flow cytometry data also showed an overlapping of common cyanobacteria at all 12 study sites including Synechococcus sp. IU 625 like, Cylindrospermum spp. like and Anabaena spp. like cells. All sites, with the exception of Bayshore Lagoon, also had Microcystis aeruginosa like cells present within the sample. PCR results demonstrated that general bacteria, phytospecific bacteria, and cyanobacteria were present within the samples as expected given the history of Barnegat Bay and CHABs. However, there was no toxin producing Microcystis aeruginosa identified within any of the 12 collection sites. This may reflect the fact the gene targeted mcyA (Microcystin synthetase A) in using the MSF/MSR primer pair is responsible for the toxin biosynthesis. These finding may suggest that we have $M$. aeruginosa that is a non-toxin producer. Further experiments should be carried out for verification.

An additional part of our study was to determine the presence of cyanophages within the surface water of these 12 sites using plaque assays. It was found that all 12 sites were positive for cyanophages using a mixed cyanobacterial culture. It was also found that for individual strains such as Synechococcus sp. IU 625, Microcystis aeruginosa 2385, and Anabaena all had cyanophages that targeted those individual cyanobacteria strains when the concentrated lysate was added. This indicates that not only can cyanophages act when provided a mix of different hosts, they also have activity in the presence of individual hosts. Areas with lower plaques densities may be of concern since they might be less likely to affect biocontrol on native cyanobacterial populations and the production of CHABs. In contrast, no cyanophages were detected using Oscillatoria spp. as the host for the individual strain viral plaque assays. According to the flow cytometry analysis there was no Oscillatoria spp. like cells found within the 12 collection sites. Given that information, it is not surprising that there are no Oscillatoria spp. specific cyanophages present if there is possibly no Oscillatoria spp. to act as hosts within the samples. The understanding of cyanophage populations is important due to the fact that it can potentially be used as a CHAB control by reducing the amount of cyanobacteria in a biological rather than chemical methods that are currently in use [21].

In the future it may be prudent to employ more species-specific primers to 
identify the cyanobacteria and cyanophage populations. This is also an area where next generation sequencing (NGS) methodologies can be most informative. We plan to investigate the differences between areas of the bay influenced by the thermal plume of the Oyster Creek nuclear generating station and those further removed. Although the long-term consequences of chronic thermal pollution generated by nuclear power plants such as Oyster Creek is uncertain, we anticipate that a combination of several methodologies may shed light on the biological consequences of such thermal stress and serve as a model for global warming.

\section{Conclusion}

Surface water collections within Barnegat Bay determined the presence of $C y$ lindrospermum spp., Anabaena spp., and Synechococcus sp. IU 625 like species, while 11 of the 12 sites contained Microcystis aeruginosa like species via flow cytometry. PCR analyses indicated the presence of universal bacteria, phytospecific species, and cyanobacteria, but determined that there was no presence of toxin-producing Microcystis aeruginosa. Consequently, there is a difference in results between flow cytometry and PCR analysis and suggests that multiple methods may be necessary to validate the presence of CHABs in coastal waters. Viral plaque assays contained cyanophages that formed plaques on mixed cyanobacteria and cyanophages that targeted Anabaena spp., Synechococcus sp. IU 625, and Microcystis aeruginosa. A few sites had cyanophages that targeted Cylindrospermum spp., but none of the 12 sites contained cyanophages that targeted Oscillatoria spp. Consequently, Barnegat Bay has a robust diversity of both cyanobacteria and cyanophages, which provides an auto-correcting dynamic interaction between host and phages which may serve to minimize CHABs.

\section{Author Contributions}

Conceptualization, T.C.; methodology, R.R. and T.C.; investigation, R.R., A.G., A.N., C.R.-R., Y.W., P.Y.; resources, D.R., J.G., P.B., and T.C.; data curation, R.R. and T.C.; writing — original draft preparation, R.R.; writing—review and editing, D.R., J.G., P.B., and T.C.; visualization, R.R. and T.C.; supervision, T.C..; project administration, T.C.; funding acquisition, T.C.

\section{Acknowledgements}

This research was funded by Seton Hall University (SHU) Department of Biological Sciences Graduate Teaching Assistantship to P.Y.; SHU Department of Biological Sciences Annual Research Fund and William and Doreen Wong Foundation to T.C.

\section{Conflicts of Interest}

The authors declare no conflicts of interest regarding the publication of this paper. 


\section{References}

[1] D’Anglada, L.V., Donohue, J.M. and Strong, J. (2015) Health Effects Support Document for the Cyanobacterial Toxin Microcystins. USEPA, Washington DC.

[2] Funari, E. and Testai, E. (2008) Human Health Risk Assessment Related to Cyanotoxins Exposure. Critical Reviews in Toxicology, 38, 97-125. https://doi.org/10.1080/10408440701749454

[3] Sellner, K.G., Doucette, G.J. and Kirkpatrick, G.J. (2003) Harmful Algal Blooms: Causes, Impacts and Detection. Journal of Industrial Microbiology and Biotechnology, 30, 383-406. https://doi.org/10.1007/s10295-003-0074-9

[4] Masten, S.C.B. (2001) Cylindrospermopsin-Review of Toxicological Literature. Toxicological Summary for Cylindrospermopsin. Final Report 2000. In: Sciences, NIOEH, Ed., Research Triangle Park, NC.

[5] USEPA (2014) Cyanobacteria and Cyanotoxins: Information for Drinking Water Systems.

[6] USEPA (2015) Health Effects Support Document for the Cyanobacterial Toxin Anatoxin-A. USEPA, Washington DC.

[7] USEPA (2015) Health Effects Support Document for the Cyanobacterial Toxin Cylindrospermopsin. USEPA, Washington DC.

[8] USEPA (2015) Drinking Water Health Advisories for Two Cyanobacterial Toxins. USEPA, Washington DC.

[9] van Apeldoorn, M.E., van Egmond, H.P., Speijers, G.J. and Bakker, G.J. (2007) Toxins of Cyanobacteria. Molecular Nutrition \& Food Research, 51, 7-60. https://doi.org/10.1002/mnfr.200600185

[10] Anderson, D.M., Gilbert, P.M. and Burkholder, J.M. (2002) Harmful Algal Blooms and Eutrophication: Nutrient Sources, Composition, and Consequences. Estuaries, 25, 704-726. https://doi.org/10.1007/BF02804901

[11] Kennish, M.J., Bricker, S.B., Dennison, W.C., Glibert, P.M., Livingston, R.J., Moore, K.A., Noble, R.T., Paerl, H.W., Ramstack, J.M., Seitzinger, S., Tomasko, D.A. and Valiela, I. (2007) Barnegat Bay-Little Egg Harbor Estuary: Case Study of a Highly Eutrophic Coastal Bay System. Ecological Applications, 17, S3-S16. https://doi.org/10.1890/05-0800.1

[12] Hermanson, G.T. (2013) Fluorescent Probes. In: Bioconjugate Techniques, Third Edition, Academic Press, New York, 395-463. https://doi.org/10.1016/B978-0-12-382239-0.00010-8

[13] Patel, R., de Oliveira, A., Newby, R. and Chu, T. (2019) Flow Cytometric Analysis of Freshwater Cyanobacteria: A Case Study. Water, 11, 1422. https://doi.org/10.3390/w11071422

[14] Dennis, M.A., Landman, M., Wood, S.A. and Hamilton, D. (2011) Application of Flow Cytometry for Examining Phytoplankton Succession in Two Eutrophic Lakes. Water Science \& Technology, 64, 999-1008.

[15] Christaki, E., Bonos, E. and Florou-Paneri, P. (2015) Innovative Microalgae Pigments as Functional Ingredients in Nutrition. In: Kim, S.-K. Ed., Handbook of Marine Microalgae: Biotechnology Advances, Elsevier Academic Press, London, 233-243. https://doi.org/10.1016/B978-0-12-800776-1.00014-5

[16] MacColl, R. (1998) Cyanobacterial Phycobilisomes. Journal of Structural Biology, 124, 311-334. https://doi.org/10.1006/jsbi.1998.4062

[17] Telford, W.G., Moss, M.W., Morseman, J.P. and Allnutt, F.C. (2001) Cyanobacterial 
Stabilized Phycobilisomes as Fluorochromes for Extracellular Antigen Detection by Flow Cytometry. Journal of Immunological Methods, 254, 13-30. https://doi.org/10.1016/S0022-1759(01)00367-2

[18] Chu, T.C., Wu, M., Pohren, L., Haghjoo, B., Soman, C. and Lee, L.H. (2014) Molecular Identification of a Fungal Pathogen Batrachochytrium dendrobatidis and Its Impact on Urbanized New Jersey. Advances in Microbiology, 4, 1164-1173. https://doi.org/10.4236/aim.2014.416126

[19] Lee, L.H., Wu, M., Peri, A. and Chu, T. (2014) Method Evaluations of Escherichia coli and Coliform Detection in Northern New Jersey. GSTF Journal of BioSciences, 3, 40-45.

[20] Chu, T.C., Murray, S.R., Hsu, S.F., Vega, Q. and Lee, L.H. (2011) Temperature-Induced Activation of Freshwater Cyanophage AS-1 Prophage. Acta Histochemica, 113, 294-299. https://doi.org/10.1016/j.acthis.2009.11.003

[21] Lee, L.H., Lui, D., Platner, P.J., Hsu, S.F., Chu, T.C., Gaynor, J.J., Vega, Q.C. and Lustigman, B.K. (2006) Induction of Temperate Cyanophage AS-1 by Heavy Metal-Copper. BMC Microbiology, 6, 17. https://doi.org/10.1186/1471-2180-6-17

[22] Rahman, R.M. (2019) Detection, Identification, and Metagenomic Characterization of Cyanobacteria in Barnegat Bay, New Jersey. Seton Hall University, South Orange, NJ.

[23] Barkovskii, A.L. and Fukui, H. (2004) A Simple Method for Differential Isolation of Freely Dispersed and Particle-Associated Peat Microorganisms. Journal of Microbiological Methods, 56, 93-105. https://doi.org/10.1016/j.mimet.2003.09.005

[24] Nubel, U., Garcia-Pichel, F. and Muyzer, G. (1997) PCR Primers to Amplify 16S rRNA Genes from Cyanobacteria. Applied and Environmental Microbiology, 63, 3327-3332.

[25] Stiller, J.W. and McClanahan, A. (2005) Phyto-Specific 16S rDNA PCR Primers for Recovering Algal and Plant Sequences from Mixed Samples. Molecular Ecology Notes, 5, 1-3.https://doi.org/10.1111/j.1471-8286.2004.00805.x

[26] Tillett, D., Parker, D.L. and Neilan, B.A. (2001) Detection of Toxigenicity by a Probe for the Microcystin Synthetase A Gene (mcyA) of the Cyanobacterial Genus Microcystis. Comparison of Toxicities with 16S rRNA and Phycocyanin Operon (Phycocyanin Intergenic Spacer) Phylogenies. Applied and Environmental Microbiology, 67, 2810-2818. https://doi.org/10.1128/AEM.67.6.2810-2818.2001

[27] Rutten, T.P., Sandee, B. and Hofman, A.R. (2005) Phytoplankton Monitoring by High Performance Flow Cytometry: A Successful Approach? Cytometry Part A, 64, 16-26. https://doi.org/10.1002/cyto.a.20106 